NBER WORKING PAPER SERIES

\title{
INFLATION AND THE USER COST \\ OF CAPITAL: DOES INFLATION \\ STILL MATTER?
}

\author{
Darrel Cohen \\ Kevin A. Hassett \\ R. Glenn Hubbard
}

Working Paper 6046
NATIONAL BUREAU OF ECONOMIC RESEARCH 1050 Massachusetts Avenue
Cambridge, MA 02138
May 1997

The paper was prepared for presentation at the NBER Conference on the Costs and Benefits of Achieving Price Stability, Federal Reserve Bank of New York, February 20-21, 1997. We are grateful to Alan Auerbach, Martin Feldstein, Benjamin Friedman, Robert Hodrick, Larry Meyer, Edmund Phelps, and participants in the Columbia Macro Lunch Group and NBER Conference on the Costs and Benefits of Achieving Price Stability for helpful comments and suggestions. This paper does not necessarily reflect the views or opinions of the Board of Governors of the Federal Reserve System or the National Bureau of Economic Research. This paper is part of NBER's research programs in Economic Fluctuations and Growth, Monetary Economics and Public Economics.

(C) 1997 by Darrel Cohen, Kevin A. Hassett and R. Glenn Hubbard. All rights reserved. Short sections of text, not to exceed two paragraphs, may be quoted without explicit permission provided that full credit, including (O) notice, is given to the source. 
Inflation and the User Cost of Capital: Does

Inflation Still Matter?

Darrel Cohen, Kevin A. Hassett and R. Glenn Hubbard

NBER Working Paper No. 6046

May 1997

JEL Nos. E5, E6

Economic Fluctuations and Growth,

Monetary Economics and Public Economics

\begin{abstract}
$\underline{\text { ABSTRACT }}$
In the late $1970 \mathrm{~s}$, many economists argued that the deleterious effects of inflation on the user cost of capital for U.S. firms were large. Since that time, the tax code has changed, the level of inflation has dropped significantly, and the "canonical" model of investment has evolved considerably. In this paper, we demonstrate that the net effect of these changes has--under reasonable assumptions--not relegated inflation to the sidelines. Indeed, we conclude that: (1) inflation, even at its relatively low current rates, continues to increase the user cost of capital significantly; (2) the marginal gain in investment in response to a percentage-point reduction in inflation is larger for lower levels of inflation; (3) the beneficial effects for steady-state consumption of lowering inflation even further than has been achieved to date would likely be significant; and (4) inflation has only a small impact on intratemporal distortion in the allocation of capital within the domestic business sector. We also show that the magnitude of the inflation effect on the user cost of capital is likely much smaller in open economies.
\end{abstract}

Darrel Cohen

Stop 83

Board of Governors of the

Federal Reserve System

Washington, DC 20551

m1dsc99@frb.gov

R. Glenn Hubbard

Graduate School of Business

Columbia University

609 Uris Hall

New York, NY 10027

and NBER

ghubbard@research.gsb.columbia.edu
Kevin A. Hassett

Stop 80

Board of Governors of the

Federal Reserve System

Washington, DC 20551

mlkah99@frb.gov 


\section{INTRODUCTION}

High and rising rates of inflation in the United States during the 1970s stimulated economists to examine the effects of inflation on household and business decisions about household saving and business investment (see, e.g., Darby, 1975; Feldstein, 1976; Feldstein, Green, and Sheshinski, 1978; Auerbach, 1981; and Gordon, 1984). Indeed, a substantial body of research has concluded that one of the most important channels through which a change in the anticipated rate of price inflation can affect real economic activity is a nominal-based capital income tax structure (see Feldstein, 1983). ${ }^{1}$ In the United States, for example, nominal interest payments are treated as tax deductions by businesses and taxable income by investors, capital gains are taxed without an adjustment for inflation, and depreciation is written off on a historical cost basis. While these features of the tax code have not changed in the past twenty years, other features--such as the corporate income tax rate and depreciation schedules--have changed considerably. In addition to these tax changes, the period has experienced a dramatic increase in the flow of capital across national boundaries. While the United States may not face a perfectly elastic supply of foreign capital, rates of return in U.S. capital markets have become more closely linked to foreign returns.

Most of the existing studies of the effect of anticipated inflation on the effective tax on business investment were written during periods of significant -- at least by U.S. standards -inflation. In recent papers, Feldstein (1996) and Abel (1996), using different methodological approaches, estimate significant welfare gains from greater business capital accumulation from

1 Other distortions include those in the demand for money (see, e.g., Bailey, 1956; and Feldstein, 1979) and in investment in housing (see, e.g., Poterba, 1984) For general overviews of the costs of inflation, see e.g., Fischer (1981), Feldstein (1996), and Hubbard (1997). 
reducing even modest rates of inflation. ${ }^{2}$ Indeed, the present value of gains from reducing inflation substantially exceeds the costs of disinflation estimated by Ball (1994).

In this paper, we extend prior approaches to estimating the impact of domestic inflation on business investment -- based on subsequent modifications to the tax code, the increasing openness of world capital markets, and recent developments in the theoretical modeling of investment decisions. In particular, we quantify the impact of an immediate and permanent change in the rate of inflation on the user cost of capital for different types of assets in a partial equilibrium framework. ${ }^{3}$ In addition, we show the relationship between the resulting inflation sensitivity of the user cost and the choice of capital durability. We also present estimates of the sensitivity of current investment incentives to anticipated changes in future rates of inflation and explore the effects of inflation on steady-state consumption. Finally, we present estimates of the impact of inflation on intratemporal distortions in the allocation of capital.

In brief, we conclude that for the United States: (1) inflation, even at its relatively low current rates, continues to increase the user cost of capital significantly; (2) the marginal percentage

2 In both sets of estimates, the gains from a reduced distortion in the allocation of lifetime consumption between early years and later years account for the vast majority of total welfare gains from disinflation.

${ }^{3}$ In our analysis of the effects of inflation on the effective tax rate on investment, we assume that there is no correlation between changes in capital income tax rates and changes in inflation. That is, we do not allow for the possibility that the legislative process takes into account the effect of inflation on the effective tax burden when deciding on individual and corporate tax rates. It might be the case, for example, that the Congress would introduce more generous depreciation allowances or lower statutory tax rates on capital gains when inflation is higher. While there is some discussion of this connection in the context of the Economic Recovery Tax Act of 1981 (see Joint Committee on Taxation, 1981), we could find no record of such discussion in the debate over the Tax Reform Act of 1986 and the Onnibus Budget Reconciliation Act of 1993 (the tax acts governing the current period we analyze). 
reduction in the user cost of capital per percentage-point reduction in inflation is higher the lower the level of inflation; (3) the beneficial effects of lowering inflation even further than has been achieved to date would be notable; and (4) inflation has almost no impact on intratemporal distortions in the allocation of capital within the domestic business sector. These conclusions support the arguments by Feldstein (1996) that there are potentially significant economic benefits of reducing even modest levels of inflation for the U.S. economy. However, we also show that there is a great deal of uncertainty concerning the relevance of these conclusions for small open economies.

By focusing on the effects of disinflation on the user cost of capital and the capital stock, we are abstracting from two general questions. First, we do not present estimates of the welfare gains from the higher capital stock made possible by lower inflation. ${ }^{4}$ Second, we do not attempt to estimate the optimal rate of inflation. Such a calculation requires a more comprehensive model of the costs and benefits of inflation.

The remainder of the paper is organized as follows. In section II, we analyze the theoretical linkages between inflation and the user cost of capital. In section III, we present empirical estimates of the effects of an immediate and permanent change in the rate of inflation on the user cost for different types of capital, taking into account the details of current U.S. corporate tax law. Section IV extends these results by analyzing the impact on the user cost of anticipated future changes in the rate of inflation. In section $\mathrm{V}$, we examine the effects of lower inflation on steady-state

\footnotetext{
${ }^{4}$ To do so would require separating transition gains and losses from steady-state efficiency gains, which is beyond the scope of this paper. As we argue in section VII, however, under the assumption that the United States is a closed economy, one can use golden rule calculations to argue that the level of the fixed nonresidential capital stock is too low.
} 
consumption. Section VI examines the effects of inflation on the welfare losses associated with differential taxation of capital. In the final section, we offer some concluding thoughts and directions for future research.

\section{INFLATION AND THE USER COST OF CAPITAL}

\section{A. Inflation and the Cost of Funds}

Firms can obtain their financing from three sources: they can issue debt, equity, or they can use internal funds. In this section, we discuss the effects of the interaction of inflation and tax variables on the marginal cost of finance for U.S. firms from these different sources. The effects depend importantly on open economy issues, in particular the degree of openness of international capital markets. For simplicity, however, we begin with a discussion of effects of inflation on the cost of funds in a closed U.S. capital market; then we expand the analysis to incorporate an open capital market and the international tax regime.

Debt Finance. In a closed economy, U.S. holders of corporate debt are assumed to require a fixed real after-tax rate of return, $r,{ }^{5}$ where:

${ }^{5}$ The assumption of a constant real rate of interest represents the traditional Fisher hypothesis (see Fisher, 1930). The Fisher hypothesis need not hold in the presence of the inflation - tax interactions that we analyze here. Indeed, if the only nonneutrality of interest were the deductibility and taxability of nominal interest payments for debt-financed investments, nominal interest rates would rise more than one-for-one with anticipated inflation (see Feldstein, 1976). Offsetting this consideration, as we note below, are other tax nonneutralities, the presence of equity finance, and international capital mobility (see also Hartman, 1979; Feldstein, 1983; Hansson and Stuart, 1986; and Bayoumi and Gagnon, 1996). Empirical evidence presented by Mishkin (1992) and by Bayoumi and Gagnon (1996) argues that the real pre-tax rate of interest is not affected by a change in expected inflation.

We investigated these empirical estimates: Using the nominal one-year Treasury bill rate, the Livingston measure of expected (one-year-ahead) inflation, and a time-series of the effective 


$$
r=R\left(1-\tau_{p}\right)-\Pi,
$$

and

$R=$ nominal interest rate on corporate debt

$\tau_{\mathrm{p}}=$ marginal personal tax rate on interest income

$\pi=$ expected rate of inflation.

This expression for the real return on funds loaned reflects the fact that, under current U.S. tax law, nominal interest income--which includes both the real and the inflation premium components of market interest rates--is taxable to bondholders. For a given $r$ and $\pi$, a reduction in the marginal tax rate of the holder of debt lowers the nominal interest rates that firms pay, and, for a given $r$ and $\tau_{p}$, a one-percentage-point reduction in the rate of inflation lowers the interest rates that firms pay by more than one percentage point. In addition to the tax-adjusted Fisher effect, we also examine the case in which the real before-tax interest rate is held constant, which is especially relevant for a small open economy; with this assumption, a one percentage-point reduction in the rate of inflation raises the real after-tax interest rate, $r$, by $\tau_{\mathrm{p}}$ percentage points.

The firm's real cost of debt, $\rho_{d}$, depends on its own marginal income tax rate, $\tau_{c}$ :

$$
\rho_{d}=R\left(1-\tau_{c}\right)-\Pi .
$$

Expression (2) reflects the deductibility of nominal interest payments on corporate debt under current

marginal tax rate on interest income of Prakken, Varvares, and Meyer (1991), we find that both the nominal before-tax rate and the after-tax rate are cointegrated with the expected inflation measure and that both the real before-tax rate and the real after-tax rate are stationary. We view this as providing ambiguous evidence of whether the tax-adjusted or non-tax-adjusted Fisher effect holds. In any case, the fact that results of Prakken, Varvares, and Meyer show that taxes are in fact paid on interest income at a rate between zero and the maximum statutory rate suggests that the marginal investor may well be taxable and that the tax-adjusted Fisher effect is a reasonable case to examine. 
law. Combining (1) and (2) yields the firm's real cost of debt from the perspective of the ultimate supplier of debt capital rather than from the firm's manager:

$$
\begin{aligned}
\rho_{d} & =(r+\Pi) \frac{\left(1-\tau_{c}\right)}{\left(1-\tau_{p}\right)}-\Pi \\
& =\frac{r\left(1-\tau_{c}\right)}{\left(1-\tau_{p}\right)}+\Pi \frac{\left(\tau_{p}-\tau_{c}\right)}{\left(1-\tau_{p}\right)}
\end{aligned}
$$

Note that, for a given real required return $r$, inflation has very little effect on the cost of debt finance if $\tau_{\mathrm{c}}$ is approximately equal to $\tau_{\mathrm{p}}$. In this case, while lower inflation reduces the nominal interest deduction, thereby raising the firm's tax liability, it also lowers the tax liability of bondholders by about the same amount. In addition, the effects of inflation on the cost of debt finance will vanish for a given required real after-tax return if firms are required to deduct only real, rather than nominal, interest payments and if bondholders are allowed to include only real interest income in taxable income. Such would be the case with a fully indexed tax structure. ${ }^{6}$ Note also that the effects of inflation on the cost of debt finance depend crucially on the assumption that the marginal debtholder is taxable at the statutory rate $\tau_{\mathrm{p}}$. If the marginal debt holder is a financial intermediary such as a pension plan (whose income is non-taxable under current law), then lower

6 With the tax structure indexed for inflation, bondholders' real after-tax rate of return becomes $r=(R-\pi)\left(1-\tau_{\mathrm{p}}\right)$, while firm's real cost of debt becomes $\rho_{\mathrm{d}}=(R-\pi)\left(1-\tau_{\mathrm{c}}\right)$. Combining these two expressions yields $\rho_{d}=r\left(1-\tau_{c}\right) /\left(1-\tau_{p}\right)$, which is independent of the rate of inflation for a given $r$. 
inflation can increase the cost of debt finance. Firms receive smaller interest deductions, and pension funds do not accrue an offsetting decrease in tax liability. Although convincing evidence of the tax rate of the marginal debt holder in the United States probably is not available, we would reiterate the observation made above that taxes appear to be paid on interest income at a fairly high effective rate, lending some support for the proposition that the effects of inflation on the user cost through the debt channel will be relatively small.

The results differ somewhat in the case of integration of the U.S. capital market with an open international capital market. In particular, the results depend on the degree to which the United States exerts market power and on the extremely complicated details of international tax law. At one extreme, one could assume that the United States is so large that it determines all relevant market and tax conditions; this assumption essentially reduces to the prior closed-economy case. By contrast, if the United States participates as a price taker in a world with perfect international capital mobility, the real cost of debt is determined in world capital markets, and is exogenously given to U.S. firms. ${ }^{7}$ Moreover, under a pure residence-based income tax structure, which is likely to be the most relevant modeling assumption in the case of international taxes on interest income, the interest rate that U.S. corporations must pay on their debt obligations may be independent both of domestic and foreign tax rates on interest income. ${ }^{8}$

${ }^{7}$ Hartman argues that, when taxes are taken into consideration, domestic inflation in a small open economy raises the desired capital stock and reduces domestic saving, thereby increasing capital inflows from the rest of the world. Empirical support for this proposition is provided by Bayoumi and Gagnon (1996).

${ }^{8}$ A residence-based tax system can be summarized briefly as follows. If country $\mathrm{A}$ has a residence-based tax system applicable to interest income, the residents of country A are taxed uniformly on their worldwide interest income, regardless of whether the source of that income is 
With perfectly integrated capital markets (and no transactions or information costs), uncovered or open interest parity holds. That is, for a marginal risk-neutral investor, the nominal after-tax rate of return on U.S. debt instruments equals the exogenous after-tax rate of return on a foreign debt instrument plus the expected percentage rate of depreciation of the dollar relative to foreign currencies. With residence-based taxation, the applicable tax rate for a U.S. investor is the U.S. tax rate, while the applicable tax rate for the foreign investor is the foreign tax rate. This implies two separate parity conditions. For the U.S. investor we have: $R\left(1-\tau_{p}\right)=R^{*}\left(1-\tau_{p}\right)+\Delta s^{e}$ $\left(1-\tau_{g}\right)$, where $s^{e}$ denotes the expected log future spot dollar value of foreign exchange, $R^{*}$ denotes the exogenous foreign nominal interest rate, and $\tau_{\mathrm{g}}$ represents the U.S. tax rate on foreign exchange gains; this condition implies that U.S. investors are indifferent between investing at home or abroad. Similarly, for the foreign investor, the parity condition is:

$R\left(1-\tau_{\mathrm{p}}^{*}\right)=R^{*}\left(1-\tau_{\mathrm{p}}^{*}\right)+\Delta s^{\mathrm{e}}\left(1-\tau_{\mathrm{g}}^{*}\right)$, where $\tau_{\mathrm{p}}^{*}$ denotes the foreign tax rate on interest income, and $\tau_{\mathrm{g}}{ }_{\mathrm{g}}$ represents the foreign tax rate on foreign exchange gains. ${ }^{9}$ If $\tau_{\mathrm{p}} \approx \tau_{\mathrm{g}}$ and $\tau_{\mathrm{p}}{ }_{\mathrm{p}} \approx \tau_{\mathrm{g}}{ }^{*}$, then the international arbitrage relationships imply the equality of pre-tax interest rates (adjusted for expected exchange rate changes). In this case, the interest rate that U.S. corporations must pay on their debt

country A or the rest of the world; nonresidents are not taxed by country A on their income originating in that country. In fact, residence-based taxation of interest income holds approximately in the United States and many other countries (see Hubbard, 1995; and Hines and Hubbard, 1995 for a more complete discussion of international tax law). Such a tax structure generates a particular form of international arbitrage or parity relationships.

9 Desai and Hines (1997) discuss complications arising from differences in the taxation of interest income and foreign exchange gains and losses, and illustrate the effects of changes in inflation on international capital flows. 
is not influenced by either the U.S. or foreign tax rates on interest income. ${ }^{10}$ In a small-openeconomy setting in which purchasing power parity holds (which implies that $\Delta s^{e}=\pi-\pi^{*}$, where $\pi^{*}$ denotes the foreign inflation rate), then, the traditional Fisher hypothesis obtains: $d R / d \pi=d R^{*} / d \pi^{*}=1 .{ }^{11,12}$ Thus, in our work below we will consider two cases. In the "closed economy" case, the tax-adjusted Fisher effect holds. In the "open economy case," the traditional Fisher effect holds.

Equity Finance. An analogous distinction between the open and closed economy effects holds in the case of equity finance; we focus again initially on the closed-economy case. The firm's real cost of equity finance, $\rho_{\mathrm{e}}$, is defined as:

$$
\rho_{e}=D+E-\Pi,
$$

where:

$$
\begin{aligned}
& D=\text { dividend-price ratio } \\
& E=\text { investors' required ex-dividend nominal rate of return to equity. }
\end{aligned}
$$

In contrast to interest payments, dividends and retained earnings are not deductible for corporations. Individuals receive the after-tax real return:

$$
\rho_{i}=\left(1-\tau_{d}\right) D+(1-c) E-\Pi,
$$

10 In most OECD countries, tax authorities treat gains and losses on foreign currency for tax purposes as interest receipts or interest payments (see, e.g., OECD, 1992)

${ }^{11}$ Levi (1977) and Hansson and Stuart (1986) discuss complications arising when interest income and foreign exchange capital gains and losses are taxed at different rates.

${ }^{12}$ Both equalities implicitly assume that domestic and foreign inflation rates move independently. More generally, one could model the expected exchange rate change making assumptions about the relative importance of traded and nontraded goods. Such a modification would produce a different "Fisher effect" result. 
where:

$$
\begin{aligned}
& \tau_{\mathrm{d}}=\text { individual's marginal tax rate on dividend income } \\
& c=\text { individual's accrual equivalent tax rate on capital gains. }
\end{aligned}
$$

Combining terms in (4) and (5), the firm's real cost of equity finance is:

$$
\rho_{\mathrm{e}}=\frac{\left(\tau_{d}-c\right)}{(1-c)} D+\frac{\rho_{i}}{(1-c)}+\frac{c}{(1-c)} \Pi,
$$

where $i$ refers to the marginal investor.

Further, in equilibrium, investors' after-tax real returns on debt and equity, adjusted for a risk premium, $X$, must be equal, i.e., $r=\rho_{i}+X$. Solving for $\rho_{i}$ and substituting the resulting expression into (6), using (1), we get:

$$
\rho_{e}=\left[\left(\tau_{d}-c\right) /(1-c)\right] D+X /(1-c)+\left[\left(1-\tau_{p}\right) /(1-c)\right] R-\pi .
$$

Differentiation of this expression, assuming that the risk premium is unaffected by inflation and deferring consideration of the dividend term to below, we find that, for a given $r$ (i.e., in the taxadjusted Fisher effect case), lower inflation unambiguously reduces the cost of equity finance by the factor $c /(1-c)$. This term captures the "inflation tax" paid by shareholders who receive purely nominal gains; taxation of real capital gains would eliminate this effect. There is another, offsetting, effect, however, if the traditional Fisher effect holds (in which the nominal bond rate rises point-forpoint with inflation). In this case, lower inflation also raises $r$ by $\tau_{\mathrm{p}}$ times the change in inflation and, hence, $\rho_{\mathrm{i}}$ by the same amount. As a result, the total impact on the firm's real cost of equity finance in this case depends on the difference between the personal tax rate on interest and the effective capital gains tax rate. 
In addition, in the analysis that follows, we do not include the first term reflecting the tax on dividends. That is, we adopt the tax capitalization view of equity taxation (see Auerbach, 1979; Bradford, 1981; King, 1977), which suggests that the relevant equity tax rate is the effective capital gains tax rate, regardless of the amount of dividends paid. This view is premised on the assumptions that equity funds come primarily from retained earnings (i.e., lower dividends paid out of current earnings) rather than from new share issues and that earnings distributions to shareholders are primarily through dividends rather than share repurchases. The idea is that taxes on dividend distributions are capitalized into the value of the equity rather than imposing a burden on the returns to new investment, as would be the case if new investment were financed by the issue of new shares.

Turning to equity financing issues that arise in an open-economy setting, the degree of U.S. market power and complexity of the international taxation of equity returns are once again central to the analysis. If the United States is very large relative to the rest of the world, then the analysis essentially reduces to the closed-economy case. However, to the extent that the United States is a price taker, the details of international taxation of equity returns become important. In this case, the residence-based taxation discussed above in the case of debt finance no longer applies. Instead, source-based taxation is more applicable. In its pure form, source-based country taxation implies that income originating in country $\mathrm{A}$ is taxed uniformly, regardless of the residency of the recipient of the income; in addition, residents of country A are not taxed by country A on the residents' foreign-source income. For either a risk-neutral U.S. investor or foreign investor, the same parity relationship holds (assuming no expected change in the exchange rate). In this case, a viable equilibrium exists in which the U.S. equity rate of return is related to the corresponding exogenous foreign equity rate of return as well as to the domestic and foreign tax rates. 
In practice, however, tax law is much more complicated; to simplify, it is roughly the case that the United States taxes the foreign-source equity income of its residents but allows a tax credit against the taxes paid to foreign governments. The credit is limited to the product of the U.S. tax rate and the amount of foreign-source income (with carryforward and backward provisions for excess credits). Thus U.S. residents generally end up paying taxes on their foreign-source income at the higher of the foreign and U.S. tax rate, but pay at the U.S. rate on their U.S.-source income. A special provision applies to multinational firms. Foreign subsidiaries of U.S. parents are allowed to defer U.S. taxes on foreign earnings until they are repatriated, at which time taxes paid to foreign governments are credited against the U.S. tax liability (see Hines and Hubbard, 1995); deferral makes sense in periods in which foreign tax rates are lower than U.S. tax rates (see, e.g., Hines and Hubbard, 1990; and Altshuler, Newlon, and Randolph, 1995).

Assuming symmetrical treatment by foreign governments of their residents' foreign-source income, the parity conditions now depend on the difference between tax rates; if the U.S. rate is smaller than the foreign rate (i.e., if $\left.\tau^{*}>\tau\right)$ the parity relationship facing a U.S. investor compares the real after-U.S.-tax return on a U.S. equity investment with a real after-foreign-tax return on a foreign equity investment; however, the relationship facing a foreign investor is given by a comparison of the real after-foreign-tax return on a U.S. equity investment and the real after-foreigntax return on a foreign equity investment. ${ }^{13}$ An equilibrium exists in the case of tax harmonization (i.e., identical tax rates, credits, etc.). In this case, the arbitrage conditions suggest equality between pre-tax equity rates of return. For the firm in a small, open economy the world pre-tax rate of

\footnotetext{
${ }^{13}$ Cummins and Hubbard (1995) describe the effect of international tax rules and parent company foreign tax credit provisions on the cost of capital.
} 
financing $\rho_{\mathrm{e}}{ }^{*}$ is taken as given. Thus, for the firm using both debt and equity finance, $\rho_{\mathrm{e}}{ }^{*}=R^{*}\left(1-\tau_{\mathrm{c}}\right)$ - $\pi$, which holds only by accident given the absence of any equilibrating mechanism. (In general, domestic and international capital market equilibrium will hold simultaneously only if the risk premium and capital structure adjust.) Hence we focus only on the all-debt or all-equity firm in the "open-economy" examples below.

Cost of Funds. The total real cost of investment funds equals the weighted average of the cost of equity and the cost of debt:

$$
\rho=w_{d} \rho_{d}+w_{e} \rho_{e^{\prime}}
$$

where $w_{\mathrm{d}}$ and $w_{\mathrm{e}}$ are, respectively, the shares of debt and equity in total finance. For the closedeconomy simulations presented below, these weights will be treated as empirical constants, although in general they would vary with changes in tax law and inflation. For our open economy simulations, we do not explicitly impose assumptions about the weights. Rather than make arbitrary assumptions about the effect of inflation on the equilibrium risk premia and capital structure, we provide the estimates for the all-debt and all-equity cases. Of course, it is relatively easy to consider intermediate cases once one knows the values at the corners, and we do not mean to infer that all foreign companies are at financing corners. Rather, it is likely the case that the risk premium increases with indebtedness, and this serves as an equilibrating factor in explaining the observed behavior of firms in open economies.

\section{B. Corporate After-Tax Cash Flow}

We assume that managers of corporations make production and input decisions in a manner that maximizes the wealth of shareholders. In particular, firms acquire new capital so as to 
maximize the present discounted value of the generated after-corporate-tax cash flow. Before-tax cash flow is equal to revenues (net of optimal variable input costs) less the total cost of the new capital goods; in addition, taxes are paid at rate $\tau_{c}$ on revenues, with deductions allowed for depreciation and interest paid on corporate debt. Each of the terms comprising after-tax cash fiow requires some explanation.

The expected before-tax revenue stream generated by an investment is not constant over time. It declines because the economic service flow of the capital good is assumed to decay exponentially at rate $\delta$ (where this decay rate does not vary with time but does vary with the durability of the capital good), and rises because the general level of prices is assumed to increase exponentially at rate $\pi$. Moreover, the choice of asset durability--short-lived versus long-lived--is endogenous, a point to which we will return below. The total cost of new capital goods includes the purchase price, as well as installation or adjustment costs that possibly rise at an increasing rate with the quantity of investment. The cash outlays associated with financing, either through corporate debt obligations or payments to equity holders, are not included as part of cash flow; rather these financing costs are included as part of the firm's discount rate, discussed above.

Taxes also influence the firm's cash flow. In the United States, the tax treatment of capital investments has changed substantially over time (see the description in Cummins, Hassett, and Hubbard, 1994). The last major change occurred with the Tax Reform Act of 1986, which eliminated the investment tax credit and reduced the top federal statutory corporate income tax rate from 46 to 34 percent (which was increased to 35 percent in 1993). In addition, depreciation allowances were changed significantly.

Currently, only the historical or original cost of a capital asset, $H C$, may be written off even 
if the cost of replacing the asset is rising over time, and this is the nost important channel through which inflation interacts with the tax code to lower investment. Further, assets are depreciated over a fixed period of time -- the service life, $T$-- depending on the type of asset. Most machinery and equipment, so-called personal property, has a service life of seven years, although computers and light vehicles have five-year service lives and small tools three-year service lives. Commercial real property can be written off over 39 years. The dollar amount that can be written off in any year also depends on the type of asset. Personal property is allowed to be depreciated at a rate greater than that using the method of straight-line depreciation ( $=H C / T$ per year) and in this sense the depreciation on personal property is said to be accelerated. More precisely, personal property can employ the 200 percent (or double-declining-balance) method with a half-year convention in the first year and switch to straight-line when optimal. We explain this method of accelerated depreciation in detail in the Appendix. Put simply, the dollar magnitude of depreciation allowed is equivalent to that of straight-line depreciation in the first year that depreciation is taken (because of the half-year convention), greater than straight-line depreciation for the next few years, and less than straight-line depreciation for the final few years. ${ }^{14}$ Nevertheless, with a positive discount rate, the present value of depreciation allowances using this method of accelerated depreciation exceeds that using straight line. In contrast to the tax treatment of personal property, real property must be written off using the straight line method under current law. The present value of depreciation allowances per dollar invested will be denoted by $z$.

14 The part of the accelerated depreciation scheme that allows a switch to straight-line depreciation when such a switch is optimal means that the undepreciated balance remaining at the time of the switch is written off in equal increments over the remaining service life; it does not imply that a full $H C / T$ is allowed in each remaining year. 


\section{Taxes and the User Cost of Capital}

The nominal marginal cost of funds, $\rho+\pi$, where $\rho$ is given above as the total real cost of investment funds, is the discount rate that the firm applies to each component of its after-corporatetax cash flows related to investment. Maximization of the present discounted value of these cash flows over an infinite horizon, under the assumptions of no adjustment or installation costs for new capital and no change in the relative price of capital goods, $q$, implies that the pre-tax marginal product of capital today equals today's user cost of capital, $C_{\mathrm{t}}$, where:

$$
C_{\mathrm{t}}=q_{t}(\rho+\delta)\left(1-\tau_{\mathrm{c}} z\right) /\left(1-\tau_{\mathrm{c}}\right) \text {. }
$$

This is the familiar formula derived by Hall and Jorgenson (1967), which itself draws on the seminal work of Jorgenson (1963). ${ }^{15}$ If the instantaneous expected rate of change of the relative

${ }^{15}$ Switching for a moment to discrete time and assuming no corporate taxes $\left(\tau_{c}=0\right)$ or change in the price of output $(\pi=0)$, the economic logic underlying the user cost concept becomes readily apparent for the firm that finds it desirable to buy a new capital good at the beginning of period $t$ at price $q_{\mathrm{t}}^{*}$ and sell it at the beginning of the next period at a different price $q_{\mathrm{t}+1}^{*}$; there are no costs of installing the new capital and no transactions costs in its purchase or sale. Assume that the resulting increment to production, $M P K$, takes place at the beginning of period $t$, is stored costlessly during the period, and is sold at the beginning of period $t+1$ for $(p M P K)_{t+1}$, where $p$ denotes the constant price of output. Also assume that, like production, depreciation of the capital takes place at the beginning of the period and assume that the firm spends $\delta q_{t}^{*}$ at the beginning of the period to replace the worn out $\delta$ units of capital. If $\rho$ is the required rate of return for investors, then the present value of the net cash flow is given by: $-q_{t}^{*}-\delta q_{\mathrm{t}}^{*}+[(p$ $\left.M P K)_{t+1}+q_{t+1}^{*}\right] /(1+\rho)$ which equals zero for a marginal investment. Rearranging this expression yields: $\quad(p M P K)_{t+1}=q_{\mathrm{t}}^{*}\left[\rho+\delta+\rho \delta-\left(\Delta q_{\mathrm{t}+1}^{*} / q^{*}\right)\right]$, where $\Delta q_{t+1}^{*} / q_{\mathrm{t}}^{*}$ denotes the capital gain or loss on the asset due to a change in its market price; in our simple example, the capital gain or loss is realized, but in general it may be accrued rather than realized. Note that the expression arising in the one-period problem approximates the above continuous time version of the user cost (with no corporate taxes or change in output prices) and, indeed, the interaction term, $\rho \delta$, vanishes in continuous time.

Put another way, with no corporate taxes the firm's cost of capital in use has three components: the first is the combined real cost of debt and equity financing, $\rho q_{t}$, which incorporates the required real rate of return of bondholders and shareholders, each on an afterpersonal-tax basis; the second is the economic rate of decay of the capital with an unchanging 
price of new capital goods, $\dot{q} / q$, is not zero, the user cost becomes:

$$
C_{t}=q_{t}(\rho+\delta-\dot{q} / q)\left(1-\tau_{c} z\right) /\left(1-\tau_{c}\right)
$$

Introduction of corporate taxes affects the user cost of capital in three ways. First, in the absence of tax deductions for depreciation and interest costs, an increase in the corporate income tax rate, $\tau_{c}$, increases the before-tax marginal product of capital necessary to yield an acceptable after-tax rate of return to investors, thereby increasing the user cost. Second, a higher corporate income tax rate increases the value of depreciation deductions and hence reduces the user cost. The multiplicative factor, $\left(1-\tau_{c} z\right) /(1-\tau)$, in the above Hall-Jorgenson expression captures the combination of these two effects; on balance, the user cost is increased under current U. S. tax law because expensing--or the immediate writeoff--of plant and equipment expenditures is not permitted (i.e., $z<1$ ). Third, a higher corporate tax rate increases the value of interest deductions and hence, all else being equal, reduces the real cost of debt finance, $\rho_{\mathrm{d}}$. Given realistic parameter values, however, the first effect dominates: On balance, corporate taxes increase the user cost or the minimum pre-tax marginal product of capital necessary to yield an acceptable real rate of return to investors. ${ }^{16}$ As a consequence, corporate taxes in the United States diminish the incentive to invest.

relative price of new capital, $\delta q_{\mathrm{t}}$; and the third is an offset due to an instantaneous real capital gain on the capital, $(\dot{q} / q) q_{\mathrm{t}}$.

16 To get a sense of the magnitudes involved for the first effect, suppose that new capital received no depreciation allowances $(z=0)$ and that the corporate income tax rate were 0.5 ; in this case, the pre-tax marginal product of capital would have to double in value relative to the no tax case. Under current law, the federal corporate income tax rate is 0.35 , while depreciation allowances for equipment investment imply that $z$ is roughly 0.75 (with an inflation rate of three percent per year); together these imply that corporate taxes raise the minimum pre-tax marginal product of equipment capital by about 15 percent. For investment in structures, depreciation 


\section{Inflation, Taxes, and the User Cost of Capital With No Adjustment Costs}

For given values of $\rho$ and $\delta$, the user cost varies directly with the rate of price inflation because the present value of depreciation--which uses the nominal rate $\rho+\pi$ for discounting-- varies inversely with inflation as a result of historical cost depreciation. Although not examined here, other treatments of this issue, such as the comparative study edited by King and Fullerton (1984), emphasize that inflation increases the "effective tax rate" on capital (the pre-tax real rate of return on a marginal investment project, net of depreciation less the post-tax real rate of return to savers, as a fraction of the former). Thus, for given values of $\rho$ and $\delta$, a reduction in the general rate of inflation creates an incentive on the margin for a higher level of capital accumulation.

In addition, the sensitivity of the user cost to expected inflation depends on the amount by which the total real corporate cost of funds, $\rho$, responds to changes in the inflation rate. As we noted above, the real cost of debt finance, $\rho_{d}$, is subject to offsetting influences in the closed-economy case. On the one hand, the tax deductibility of nominal interest payments, for a given required real after-tax return, $r$, by corporate debt holders, implies that a reduction in the general rate of inflation increases the cost of debt finance in proportion to the marginal corporate income tax rate. On the other hand, bondholders must pay taxes on their nominal interest income at the marginal personal tax rate on interest income, implying that lower inflation reduces the cost of debt finance. On balance, the effect of inflation on the cost of debt finance is proportional to the difference between

allowances imply that $z$ is about 0.40 , and corporate taxation raises the minimum pre-tax marginal product of structures by about 30 percent. The final effect of corporate taxation is to reduce the real cost of debt finance, $\rho_{d}$; given reasonable parameter values and an assumed constancy of the debt-equity ratio, this effect cuts the former effect roughly in half. 
the marginal personal and corporate income tax rates, $\tau_{p}-\tau_{c}$, and the effect vanishes if the tax rates are equal. In our "open-economy" case, however, only the former effect holds and thus lower inflation raises the cost of debt finance. In the closed economy a lower inflation rate unambiguously reduces the real cost of equity finance, $\rho_{\mathrm{e}}$, for a given required real after-tax rate of return by bondholders and, hence, shareholders (i.e., if the tax-adjusted Fisher effect holds), because of the taxation of nominal capital gains on corporate assets. By contrast, in a small, open economy, the real cost of equity finance will not depend on inflation.

\section{E Inflation, the User Cost, and the Durability of Capital}

The sensitivity of the user cost of capital to inflation also varies with the durability of capital. In the special case where the rate at which historical costs can be written off for tax purposes equals the rate of economic depreciation (assumed above to be constant over time for a given type of capital)--approximately a declining-balance method in discrete time--Auerbach (1981) establishes the result that the inflation sensitivity of the user cost declines with asset durability, for a given $\rho ;{ }^{17}$ this implies that inflation weighs more heavily on short-lived than long-lived assets, an effect that is confirmed by our simulations for personal property reported below (which also allow for $\rho$ to change with inflation). As a result, lower inflation promotes a substitution of short-lived for longlived assets, with a consequent increase in an aggregate $\delta$; this effect is not allowed for in our simulations, but if it were, the sensitivity of the user cost to inflation for personal property such as

17 Auerbach actually demonstrates the equivalent proposition that the inflation sensitivity of the required internal rate of return before taxes, $v=(c / q)-\delta$, declines with asset durability; he also shows that the inflation sensitivity of the effective corporate tax rate, $(v-\rho) / v$, declines with asset durability. 
equipment would be diminished. However, for different types of real property, we find that the inflation sensitivity of the user cost is independent of asset durability; indeed, one can show analytically that the general relationship between the two is no longer unambiguously negative with straight-line depreciation allowances. In section VI. we attempt to quantify the interasset distortions arising from inflation.

\section{F. Inflation, Taxes, and the User Cost of Capital With Adjustment Costs}

While our analysis to this point captures effects of current changes in the tax code and inflation on current incentives to invest, it omits other relevant features that might allow current incentives to depend on future changes in the tax code and inflation. For example, our assumption of no adjustment costs implies that investment decisions made today can be implemented immediately and in no way depend on either expected future financial or tax conditions. The potentially large instantaneous increment to a firm's capital stock implied by this view has long been recognized to contrast with an empirical investment process at the firm level that appears to be much smoother. This suggests that firms cannot adjust their capital stocks quickly without incurring substantial adjustment costs. If these costs rise nonlinearly with the level of capital expenditures and, perhaps, are themselves of an investment nature--such as workforce training--then firms find it desirable to spread capital expenditures over time in a manner that depends on expected future financial and tax conditions.

Jorgenson and various collaborators in the development of the neoclassical model derive an expression for the desired and actual capital stock as a function of the user cost of capital and net revenue. The gap between the desired and actual capital stock was closed by an ad hoc mechanism (such as delivery lags). A more contemporary application is offered by Auerbach (1989b). 
Auerbach begins with the Euler equation for investment and assumes a production function, productivity shocks, and convex adjustment costs. He approximates the optimal solution for perturbations by solving a linearized version of the Euler equation.

The above discussion assumes a one-time permanent change in the rate of inflation. One might also be interested in the effects of a gradual reduction in inflation. For this purpose, we can use Auerbach's result that the optimal level of investment at date $t$ varies inversely with the weighted average of the current and all expected future user costs of capital, $C_{t}^{*}=E_{t} \Sigma_{s 2 t} w_{s-t} C_{s}$ where the weights, $w_{\mathrm{i}}$, sum to unity; because the weights decline exponentially, expected changes in the distant future will have relatively small effects on the current value of the user cost. In contrast to the conventional (Hall-Jorgenson) user cost formulation, the user cost also incorporates expected changes in tax parameters. Specifically, the user cost of capital at date $s$ is

$$
C_{\mathrm{s}}=q_{\mathrm{s}}\left(1-\Gamma_{\mathrm{s}}\right)\left[\rho+\delta+\Delta \Gamma_{\mathrm{s}+1} /\left(1-\Gamma_{\mathrm{s}}\right)\right] /\left(1-\tau_{\mathrm{cs}}\right) .
$$

In this expression, $\Gamma$ denotes the present value of the tax savings from depreciation allowances per dollar of investment, $D$; i.e., $\Gamma_{s}=\Sigma(1+i)^{-(t-s)} \tau, D_{t-s}$; note that depreciation allowances are discounted at the default-risk-free nominal interest rate, $i$, in recognition of the fact that historically in the postwar United States legislated changes in depreciation schedules have never been applied to capital already in place nor has the corporate income tax rate varied substantially (with the exception of the changes legislated in the Tax Reform Act of 1986). This formulation simplifies to the conventional of Hall-Jorgenson formulation only if today's rate of general price inflation, the relative price of capital goods, and the tax code are expected to remain unchanged into the indefinite future (in which case $\Gamma$ does not change over time).

Such conditions are unlikely to hold in practice. Indeed, we are particularly interested in the effects on current investment incentives of a future reduction in the inflation rate, anticipated, 
perhaps, as a result of a credible long-term policy goal by the Federal Reserve to achieve a stable price level. We expand upon the analysis presented earlier of the effect of a decline in inflation on investment using the forward-looking formulation of the user cost of capital in section IV. Intuitively, if expectations of lower inflation in the future reduce future user costs and hence increase firms' long-run desired capital stock, then, in order to minimize adjustment costs, firms begin to increase investment in the current period.

\section{ESTIMATING EFFECTS OF INFLATION ON THE USER COST OF CAPITAL}

In this section, we present empirical estimates of the effects of the rate of inflation on the user cost of capital under current U.S. tax law. For purposes of this exercise, we assume that firms take inflation as given; in particular, inflation is not affected by the investment policies of firms. In addition, inflation is assumed not to affect the rate of economic depreciation, $\delta$, and tax parameters such as the corporate income tax rate and nominal depreciation allowances per dollar invested. In one set of simulations, inflation also does not affect bondholders' required real after-tax rate of return, $r$, and local taxes affect the cost of equity as well. In another set, inflation does not affect the real before-tax rate of interest, $R-\pi$, or real before-tax cost of equity. Finally, our results are partial equilibrium estimates of the effect of inflation on the user cost of capital; none of our results in this section allow for the general equilibrium effects of inflation on capital formation and, hence, on the real before-tax rate of return.

Tables 1 and 2 present the user cost of three types of equipment at various inflation rates, in the closed economy case, assuming that 30 percent of inventories are subject to FIFO accounting; ${ }^{18}$

18 In the empirical work below, we assume that output is produced and held as finished goods inventories for one year; we allow for inflation's impact on inventory profits to increase the corporate tax rate by $\eta \tau \pi$, where $\eta$ is the fraction of inventories subject to FIFO accounting. This is not a fully satisfactory treatment of inventories because it treats them as entirely finished goods rather than as raw materials or work in progress. 
Table 2 assumes that no firms use FIFO accounting. Tables 3 and 4 present the same calculations for the open economy case. Tables 5 to 8 present summary results for two types of structures. The first column of each table gives the rate of price inflation, which varies. from 0 to 12 percent per annum. The remaining columns show the user cost of capital for a one-dollar investment. The estimates in the final two columns assume that $r$ is two percent per year, $\rho_{\mathrm{i}}$ is six percent per year, $\tau_{\mathrm{c}}$ is $0.35, \tau_{\mathrm{p}}$ is 0.45 , and $c$ is $0.10 .^{19}$

The results in Tables 1 and 2 show that, for each of the three types of personal property, the marginal effect of inflation on the user cost of capital is approximately independent of the rate of inflation when the economy is closed. Of course, this conclusion reflects variation in modest rates of inflation. For very high inflation, the cost of an extra percentage point of inflation may be small, because the present value of real depreciation deductions is already very low. For each type of capital asset, a one-percentage-point decline in the annual rate of inflation lowers the user cost by slightly less than one-half percentage point, no matter which assumption we make about inventory accounting. The relative unimportance of the inventory accounting method also holds in the remainder of our results, and reflects the relatively low levels of inflation explored here. The rough constancy of the relationship between the user cost and inflation implies that a reduction in the rate of inflation from a low initial level has a larger positive percentage impact on the user cost than a reduction from a high level, for any given durability of capital. Thus, if the elasticity of firm investment demand with respect to the user cost is constant, as is the case with a Cobb-Douglas

${ }^{19}$ Results for the closed-economy case are sensitive to the choice of $\tau_{p}$; the impact of inflation on the user cost of capital is independent of $\tau_{p}$ in the open-economy case. Our assumed value for $\tau_{\mathrm{p}}$ of 0.45 corresponds to the (combined federal and state) rate paid by the top-bracket investor. If we, alternatively, assume that $\tau_{p}=0.21$ (based on an update of the average marginal tax rate in Prakken, Varvares, and Meyer 1991), the effects of inflation on the user cost on investment are somewhat smaller than those reported in Tables 1, 2, 5, and 6. For equipment investment, for example, each percentage point decline in inflation reduces the user cost by about one-quarter percentage points when $\tau_{p}=0.21$, as opposed to one-half percentage points when $\tau_{p}=0.45$. 
production technology, the beneficial impact on the incentive to invest of lowering the rate of inflation from its current level of about three percent per year to zero may be greater than the beneficial effect of lowering it by three percent from the higher levels that prevailed in the United States during the late 1970 s and early 1980 s.

Tables 3 and 4 indicate how our results change for a small open economy. When the marginal source of finance is new equity issuance, then the results are comparable to the closedeconomy case, but when the marginal source of finance is debt, then the deductibility of interest payments is important enough to reverse the results. The results for structures are qualitativeiy similar to those for equipment, although there are quantitative differences. Clearly, the choice of marginal finance source is the dominant factor in the open-economy case.

Another interesting finding follows from the fact that the response of the user cost to small changes in inflation is not constant across either types of capital or levels of inflation. A large change in the inflation rate, say ten percentage points, has a differential effect on the user cost depending on the durability of capital. In particular, a large increase in the inflation rate raises the user cost of assets (or limits the decline in the open-economy debt-finance case) with a three-year service life more than those with a five-year or a seven-year life, but variation across real property assets is essentially nonexistent. These findings are consistent with the discussion in section IIE, where we argued on analytic grounds that the inflation sensitivity of the user cost declines unambiguously with asset durability in the case of assets, such as equipment, that can be written off using a declining-balance method of depreciation, but that the relationship is ambiguous in the case of assets, such as structures, that are subject to the straight-line method.

\section{ESTIMATING EFFECTS OF A GRADUAL REDUCTION IN INFLATION ON THE USER COST}

In this section, we present estimates of the effects of inflation on the user cost of equipment 
capital (seven-year life) and on the growth rate of the capital stock using the Auerbach formulation described earlier. The estimates are summarized in Figures 1 to 3. The top panel of each figure presents the time path of inflation, the middle panel shows the time path of the user cost, and the bottom panel shows the growth rate of the capital stock. The key assumptions are that the taxadjusted Fisher effect holds; that the elasticity of investment with respect to the user cost is -0.75 ; and that the decay rate used to calculate the weights, $w_{s}$ in $C_{t}^{*}$, which embed adjustment costs, is 0.5 , the preferred estimate in Auerbach and Hassett (1992). The figures indicate that changes in inflation can generate large effects on capital stock growth.

Figure 1 simulates a likely path investment might take if a credible commitment were announced to gradually move toward price stability. The simulation indicates that a fully anticipated decline in the inflation rate from four percent in year $t$ to zero four years later (in equal increments) begins to affect the user cost before the inflation rate actually declines because of the changes to investors expectations when the commitment is announced. Indeed, the user cost has completed about 40 percent of its total adjustment by time $t$; the full adjustment--which from Table 1 is 180 basis points-- is completed exactly four years after time $t$. The capital stock growth rate also increases in advance of the completed disinflation, rising nearly 0.5 percentage point by time $t$; the growth rate increases by nearly 1.5 percentage points when inflation equals zero and subsequently begins its decline back to the initial steady-state value. If the shock occurs while the capital stock is growing at about its historical trend rate, then this reduction in inflation will increase capital stock growth over the period by roughly 50 percent.

Figure 2 shows the effects of an even larger anticipated decline in the inflation rate from 12 percent per year, the level that obtained in the early 1980 s, to four percent over an eight-year period. Again, a sizeable part of the complete adjustment in the user cost and in the growth rate of the capital stock occurs by time $t$. Further, by the time inflation reaches four percent, the capital stock growth rate over the period has more than doubled from its initial steady-state level. In Figure 3 , we 
consider a slightly different experiment. In this case, we consider the impact on the user cost of an unanticipated increase in the inflation rate of one percentage point (from a 4 percent level) that occurs at time $t$. After time $t$, we simulate the subsequent response of the level of inflation to the shock reflecting the estimated time-series properties of the Livingston expected inflation series mentioned above. These suggest that a one-percentage-point current shock to inflation would ultimately increase the level of inflation by one and one half percentage points. The latter effect magnifies the increase in the user cost that would otherwise occur by about 20 basis points (or 50 percent).

\section{THE EFFECTS OF LOWER INFLATION ON CONSUMPTION}

Auerbach and Hassett (1991), and Cummins, Hassett, and Hubbard (1994, 1995, 1996) demonstrate that estimates of the effect of the user cost of capital (or tax-adjusted $Q$ ) on investment during major tax reforms are more likely to reflect the true underlying effect than conventional panel data estimates. ${ }^{20}$ They estimate the elasticity of the equipment investment rate with respect to its user cost in the United States to be about -0.75 and the corresponding elasticity for structures at about -0.5 . If the annual inflation rate were reduced from four percent to zero, the user cost of equipment capital, as shown above, would decline by about two percentage points, proportionally about eight percent when the tax-adjusted Fisher effect holds. Such a permanent decline in inflation would increase the equipment investment rate by about 6 percent; a similar calculation implies that the non-residential structures investment rate would increase 7.5 percent. This implies that total

20 They argue that major tax reforms offer periods in which there is substantial exogenous cross-sectional variation in the change in the user cost of capital or tax-adjusted $Q$. During reform periods, an unusually large portion of the variation in the user cost or tax-adjusted $Q$ is observable, and the signal-to-noise ratio may be much higher. Using firm-level data, an estimate using tax reforms to isolate observable variation in the user cost or $Q$ may significantly decrease the bias in the estimate of the effect on investment of the user cost or $Q$. Cummins, Hassett, and Hubbard (1996) show that this is the case for the United States and eleven other OECD countries. 
business fixed investment rises about 6.5 percent and the ratio of business fixed investment to private GDP rises about 5.5 percent.

We can now calculate the long-run gains in sustainable per capita real private consumption that would result from the permanent reduction in inflation. ${ }^{21}$ In the steady-state, investment is proportional to the capital stock and, hence, the investment-output and capital-output ratios are proportional. Thus, eventually, the 5.5 percent increase in the investment-output ratio boosts the capital-output ratio by the same percentage amount. This implies that eventually output per worker rises 2.2 percent, assuming a Cobb-Douglas production technology with capital's share equal to 0.3 and, hence, an elasticity of output per worker with respect the the capital-output ratio equal to 0.4 . Thus, investment per worker (equal to output per worker times the investment-output ratio) rises 7.7 percent. It follows that private consumption per worker, whose increase equals the weighted percentage growth of output per worker less the weighted percentage growth of investment per worker, eventually rises 1.3 percent permanently,

Our estimate of the effect of inflation-induced changes in the user cost of capital on investment is determined in a partial equilibrium setting. The estimate implicitly assumes that the supply of funds to the domestic business sector is perfectly elastic. To the extent that household saving and portfolio decisions (e.g., housing capital versus business fixed capital) are insensitive to changes in net returns, the increase in investment and the capital stock in response to reductions in the user cost of capital will be attenuated.

\section{INFLATION, DIFFERENTIAL TAXATION, AND CAPITAL ALLOCATION}

In addition to its effect on the overall level of capital formation, inflation can affect the

21 This calculation assumes, of course, that the supply of funds to the U.S. business sector is highly elastic. This high elasticity does not require high interest elasticity of private saving per se; funds could flow to the business sector from previously tax-favored domestic sectors (e.g., housing) or from foreign investors. 
allocation of capital, leading to distortions in the composition of the nation's capital stock. Such distortions are likely to be large when effective tax rates on capital income vary widely across assets and sectors (as, for example, in response to the Economic Recovery Tax Act of 1981 in the United States). To measure deadweight loss from nonneutral capital taxation, one needs a model with explicit decisions about saving, capital accumulation, production, and allocation of consumption. In our analysis of the intratemporal efficiency consequences for the allocation of the capital stock of a decline in inflation, we employ a simplified version of the model developed by Auerbach (1989a). Because other papers in this conference deal with intertemporal distortions in detail, we chose to simplify Auerbach's model to the static case. This is especially important in our application because critics of low inflation policies have often argued that, while low inflation can generate steady state efficiency gains, it may exacerbate intratemporal distortions by increasing the importance of differences in depreciation allowances. An assessment of the accuracy of this claim is an important component of any evaluation of the impact of inflation on investment.

The model contains a three-factor production technology (labor, capital, and land) and nine production sectors (agriculture; mining; construction; durable goods manufacturing; nondurable goods manufacturing; transportation, communication, and utilities; wholesale and retail trade; finance, insurance, and real estate; and other services). Each industry potentially uses three fixed capital goods (equipment, nonresidential structures, and residential structures).

Solving the model requires a set of assumptions about technology and preferences. On the technology side, the production function for each sector is of the nested CES form, requiring assumptions about the elasticity of substitution among land and capital goods and the elasticity between each of these and labor. On the preferences side, the household utility function is of the nested CES form, with leisure in the first-period nest, requiring assumptions about the intratemporal elasticity of substitution in each period, the intertemporal elasticity of substitution, and the fraction of hours worked in the initial equilibrium. For the baseline case, we adopt the set of parameters 
adopted by Auerbach (1989a).

Table 9 contains our estimates of the change in intratemporal distortion attributable to a permanent reduction of inflation from four percent to zero. We assume that the tax on residential structures is zero, and the tax on labor is 0.5 . Prior to the inflation reduction, the effective tax rate on nonresidential structures is assumed to be 0.425 , and the effective tax rate on equipment is assumed to be 0.37 (both values taken from Fullerton and Karayannis, 1993). After the reduction, we estimate that the effective tax rate on structures drops to 0.39 , while that on equipment drops to 0.31. The table contains our estimates of the effect of this drop on the intratemporal distortion. For base case values of the elasticity of substitution between capital goods, and between capital and labor, the change in the distortion is almost zero. The relative insensitivity of the intratemporal distortion likely reflects the overwhelming impact of the low tax on residential capital. Thus it seems unlikely that sizable intratemporal distortions can offset the intertemporal gains estimated by Feldstein (1996).

While Auerbach's model accounts for the distortion arising from inflation nonneutralities in the tax system because of differences in capital intensity across different consumption-goodsproducing sectors, for tradeable goods, such distortions are unimportant because goods prices are set in an international market. For nontraded goods, however, a reduction in the user cost of capital accompanying a decline in inflation reduces the price of relatively capital-intensive goods, so that the Auerbach model applies. Many of the most capital-intensive sectors (measure by capital-labor ratios) identified by Fullerton and Rogers (1997) produce nontraded goods (e.g., real estate and transportation, communications, and utilities). Moreover, efficiency gains from reducing capital taxes actually benefit (relatively) low-income households because of the capital intensity of the weighted average of goods consumed by those households (see Fullerton and Rogers, 1997). Thus there may well be distributional benefits to lowering inflation as well. This is an important topic for future research. 


\section{CONCLUSIONS AND DIRECTIONS FOR FUTURE RESEARCH}

The inflation nonneutralities we have identified in the taxation of household and business capital income indicate that, given the current tax code, a reduction in inflation, all else being equal, would stimulate physical capital accumulation in the United States (unless the United States is best modeled as a small, open economy whose typical firm finances investment with debt alone). The equilibrium effects on capital formation depend in part on the responsiveness of saving and portfolio allocation to rates of return, making desirable more complete analytic integration of saving and portfolio investment decisions. While such an endeavor is beyond the scope of this paper, more research along these lines is likely to be fruitful.

Would additional physical capital accumulation made possible by lower inflation be socially valuable? Available evidence for the United States indicates that it would be, at least in the case in which the United States is assumed to be a closed economy. Reviewing predictions of several tests of dynamic efficiency, Hassett and Hubbard (1997) conclude that incentives for equipment investment have positive social returns. Cohen, Hassett, and Kennedy (1995) estimate that, for the United States, golden rule capital stocks for producers' durable equipment significantly exceed their actual levels over the past two decades. The welfare analyses in Feldstein (1996) and Abel (1996) also suggest significant welfare gains from the increased investment in response to a lower rate of inflation.

An alternative means of reaping such a gain would, of course, be to remove the inflation nonneutralities from the tax codes by, say, indexing the tax code. As long as the tax code attempts to distinguish between debt and equity, however, indexing poses significant practical difficulties (see the discussion in Feldstein, 1996). Fundamental reform of the income tax or the replacement of the income tax with a broad-based consumption tax would be required to eliminate inflation distortions 
arising from the taxation of capital income..$^{22}$

22 Under the Comprehensive Business Income Tax (see U.S. Department of the Treasury, 1992) or a consumption tax administered as the combination of a wage tax and a business cash flow tax, the user cost of capital is independent of inflation as long as real depreciation allowances are inflation-neutral and the Fisher hypothesis holds approximately; see Hubbard (1997). 


\section{Appendix: Tax Depreciation Allowances in the United States}

The amount of depreciation allowed for tax purposes on a capital investment depends on whether the asset is personal property, such as machines and tools, or real property, such as a commercial building, and on the asset's service life or cost-recovery period, $T$, stated in years. Service lives, method of depreciation (straight-line versus declining balance), and first-year conventions currently in use were established in the Tax Reform Act of 1986.

\section{A. Real Property}

Consider a $\$ 1$ investment in real non-residential property (excluding land). The service life of real non-residential property placed in service after May 1993 is 39 years. The straight-line method is used; in its simplest form this implies that, in each of the 39 years, $\$ 1 / 39$ can be written off. However, expenditure on real property is subject to a mid-month convention in the first year. For example, if the property initially is placed in service any day in January, then for tax purposes it is treated as if the starting date were in the middle of January, and hence the first-year writeoff is only $(11.5 / 12)(\$ 1 / 39)$. In general, for an initial investment in month $m$--where $m=1$ corresponds to January, $m=2$ to February, and so on--the first-year writeoff is $[(12-m+0.5) / 12](\$ 1 / 39)$. In years 2 through 39 , straight-line depreciation is allowed; in year 40 , the remaining undepreciated balance is written off.

With a nominal discount rate of $d$ percent per year, the present value of depreciation allowances for a $\$ 1$ investment in real property is given by:

$$
\begin{gathered}
z=[1 /(1+d)][(12-m+0.5) / 12](1 / \mathrm{T})+\sum_{\mathrm{I}=2}^{\mathrm{T}}[1 /(1+d)]^{\mathrm{I}}(1 / T) \\
+[1 /(1+d)]^{\mathrm{T}+1}(1 / T)[1-((12-m+0.5) / 12)] .
\end{gathered}
$$

\section{B. Personal Property}

There are several cost-recovery periods applicable to personal property. The three year class includes small tools; the five year class includes light motor vehicles and computer equipment; the seven year class includes most machinery and equipment; the ten-year, fifteen year, and twenty year 
classes include a limited number of other assets, such as land improvements. In addition, investment in personal property is subject to a mid-year convention in the first year that depreciation is taken; this convention assumes that the property is depreciable for half of the taxable year in which it is placed in service, regardless of the date it actually began to be used.

Further, personal property can be written off using the 200-percent-declining-balance (or double declining balance) method of accelerated depreciation. This method results in depreciation that is twice the straight-line amount in the first year that depreciation is taken (i.e., it is $\$ 2 / T$ for an investment of $\$ 1$ ); because of the half-year convention though, depreciation allowances in the first year are equal to the straight-line amount. In each subsequent year the acceleration factor, $2 / T$, is applied only to the remaining undepreciated balance. In the year $\mathrm{S}$ that depreciation using the double declining balance method falls below that allowed under the straight line method (as applied only to the remaining $T-S+1.5$ years), firms are allowed to switch to the straight line method. For example, the optimal year to switch is the fourth year for assets in the five year recovery class and the fifth year for assets in the seven year recovery class.

With a nominal discount rate of $d$ percent per annum, the present value of depreciation allowances for a $\$ 1$ investment in personal property with service life $T$ is given by:

$$
\begin{aligned}
z=\sum_{k=1}^{s-1}[1 /(1+d)]^{\mathrm{k}} \mathrm{D}_{k}+\sum_{k=s}^{T}[1 /(1+d)]^{\mathrm{k}}\left[1-\sum_{i=1}^{s-1} \mathrm{D}_{\mathrm{i}}\right] /(T-S+1.5) \\
{[1 /(1+d)]^{\mathrm{T}+1}(1 / 2)\left[1-\sum_{i=1}^{s-1} D_{i}\right] /(T-S+1.5), \text { where } } \\
D_{l}=(1 / 2)(2 / T)=1 / T \\
D_{2}=\left(1-D_{l}\right)(2 / T) \\
D_{3}=\left(1-D_{l}-D_{2}\right)(2 / T) \\
D_{S-l}=\left(1-\sum_{i=1}^{s-2} D_{i}\right)(2 / T) .
\end{aligned}
$$




\section{References}

Abel, Andrew B. "Comment on Feldstein." Mimeograph, Wharton School, January 1996.

Altshuler, Rosanne, T. Scott Newlon, and William C. Randolph. "Do Repatriation Taxes Matter?: Evidence from the Tax Returns of Multinationals." In Martin Feldstein, James $\mathrm{R}$. Hines, and R. Glenn Hubbard, eds., The Effects of Taxation on Multinational Corporations. Chicago: University of Chicago Press, 1995.

Auerbach, Alan J. "The Deadweight Loss from 'Non-Neutral' Capital Income Taxation." Journal of Public Economics 40 (1989a): 1-36.

Auerbach, Alan J. "Inflation and the Tax Treatment of Firm Behavior." American Economic Review 71(May 1981): 419-423.

Auerbach, Alan J. "Tax Reform and Adjustment Costs: The Impact on Investment and Market Value." International Economic Review 30 (1989b): 939-962.

Auerbach, Alan J. "Wealth Maximization and the Cost of Capital." Quarterly Journal of Economics 93 (1979): 433-446.

Auerbach, Alan J. and Kevin Hassett. "Recent U.S. Investment Behavior and the Tax Reform Act of 1986: A Disaggregate View." Carnegie-Rochester Conference Series on Public Policy 35 (Autumn 1991): 185-215.

Bailey, Martin. "The Welfare Cost of Inflationary Finance." Journal of Political Economy 64 (February 1956): 93-110.

Ball, Laurance. "What Determines the Sacrifice Ratio?" In N. Gregory Mankiw, ed., Monetary Policy. Chicago: University of Chicago Press, 1994.

Bayoumi, Tamim, and Joseph Gagnon. "Taxation and Inflation: A New Explanation for International Capital Flows." Journal of Monetary Economics 38 (1996): 303-330.

Bradford, David F. "The Incidence and Allocation Effects of a Tax on Corporate Distributions." Journal of Public Economics 15 (1981): 1-22.

Cohen, Darrel, Kevin Hassett, and Jim Kennedy, "Are U.S. Investment and Capital Stocks at Optimal Levels?" Finance and Economics Discussion Series 95-32, Board of Governors of the Federal Reserve System, July 1995.

Cummins, Jason G., Kevin A. Hassett, and R. Glenn Hubbard, "Have Tax Reforms Affected Investment?" In James M. Poterba, ed., Tax Policy and the Economy, volume 9. Cambridge: MIT Press, 1995.

Cummins, Jason G., Kevin A. Hassett, and R.Glenn Hubbard. "A Reconsideration of Investment Behavior Using Tax Reform As National Experiments." Brookings Papers on Economic Activity 2 (1994): 1-74.

Cummins, Jason G., Kevin A. Hassett, and R. Glenn Hubbard. "Tax Reforms and Investment: 
A Cross-Country Comparison." Journal of Public Economics (1996).

Cummins, Jason G., and R. Glenn Hubbard. "The Tax Sensitivity of Foreign Direct Investment: Evidence from Firm-Level Panel Data." In Martin Feldstein, James R. Hines, and R. Glenn Hubbard, eds., The Effects of Taxation on Multinational Corporations. Chicago: University of Chicago Press, 1995.

Darby, Michael. "The Financial and Tax Effects of Monetary Policy on Interest Rates." Economic Inquiry 13 (June 1975): 266-276.

Desai, Mihir A., and James R. Hines, Jr. "Efficiency Costs of Inflation-Tax Interactions in Open Economies." Mimeograph, Harvard University, February 1997.

Feldstein, Martin. "The Costs and Benefits of Going from Low Inflation to Price Stability." Working Paper No. 5469, National Bureau of Economic Research, February 1996.

Feldstein, Martin. "Inflation, Tax Rules, and the Rate of Interest: A Theoretical Analysis," American Economic Review 66 (June 1976): 809-820.

Feldstein, Martin. Inflation, Tax Rules and Capital Formation. Chicago: University of Chicago Press, 1983.

Feldstein, Martin. "Inflation, Tax Rules, and Investment: Some Econometric Evidence." Econometrica 50 (July 1987): 825-862.

Feldstein, Martin. "The Welfare Cost of Permanent Inflation and Optimal Short-Run Economic Policy." Journal of Political Economy 87 (August 1979): 749-768.

Feldstein, Martin, Jerry Green, and Eytan Sheshinki. "Inflation and Taxes in a Growing Economy With Debt and Equity Finance." Journal of Political Economy 70 (April 1978, Part 2): S53-S70.

Feldstein, Martin, and Lawrence H. Summers. "Inflation and the Taxation of Capital Income in the Corporate Sector." National Tax Journal 32 (December 1979): 445-470.

Fisher, Irving. The Theory of Interest. New York: Macmillan, 1930.

Fischer, Stanley. "Towards an Understanding of the Costs of Inflation, II." In Karl Brunner and and Allan Meltzer, eds., Carnegie-Rochester Conference Series on Public Policy 15 (1981).

Fullerton, Don, and Marios Karayannis. "United States." In Dale W. Jorgenson and Ralph Landau, eds., Tax Reform and the Cost of Capital. Washington, D.C.: Brookings Instittion, 1993.

Fullerton, Don, and Diane Lim Rogers. "Neglected Effects on the Uses Side: Even a Uniform Tax Would Change Relative Goods Prices." American Economic Review 87 (May 1997).

Gordon, Roger H. "Inflation, Taxation, and Corporate Behavior." Quarterly Journal of Economics, 94 (May 1984): 313-327.

Hall, Robert E., and Dale W. Jorgenson. "Tax Policy and Investment Behavior." American 
Economic Review 57 (June 1967): 391-414.

Hansson, Ingemar, and Charles Stuart. "The Fisher Hypothesis and International Capital Markets." Journal of Political Economy 94 (December 1986): 1330-1337.

Hassett, Kevin A., and R. Glenn Hubbard. "New Evidence Concerning the Openness of the World Market for Capital Goods." Mimeograph, Columbia University, June 1996.

Hassett, Kevin A., and R. Glenn Hubbard, "Tax Policy and Investment." In Alan J. Auerbach, ed., Fiscal Policy: Lessons from Economic Research, Cambridge; MIT Press, 1997.

Hartman, David. "Taxation and the Effects of Inflation on the Real Capital Stock in an Open Economy." International Economic Review 20 (June 1979): 417-425.

Hines, James R., Jr., and R. Glenn Hubbard. "Appendix." In Martin Feldstein, James R. Hines, Jr., and R. Glenn Hubbard, eds., Taxing Multinational Corporations. Chicago: University of Chicago Press, 1995.

Hines, James R., Jr., and R. Glenn Hubbard. "Coming Home to America: Dividend Repatriation Decisions of U.S. Multinationals." In Asssaf Razin and Joel Slemrod, eds., Taxation and the Global Economy, Chicago: University of Chicago Press, 1990.

Hubbard, R. Glenn. "How Different Are Income and Consumption Taxes?," American Economic Review 87 (May 1997).

Hubbard, R. Glenn. Money, the Financial System, and the Economy, 2nd edition. Reading: Addison-Wesley Publishing Company, 1997.

Hubbard, R. Glenn. "U.S. Tax Policy and Foreign Direct Investment: Incentives, Problems, and Reform." In Tax Policy and Economic Growth, Washington, D.C.: American Council for Capital Formation, 1995.

Jorgenson, Dale W. "Capital Theory and Investment Behavior." American Economic Review 53 (May 1963): 247-259.

Joint Committee on Taxation, U.S. Congress. General Explanation of the Economic Recovery Tax Act of 1981." H.R. 4242, 97th Congress, Public Law 97-34. Washington, D.C.: U.S. Government Printing Office, December 29, 1981.

King, Mervyn A. Public Policy and the Corporation. London: Chapman and Hall, 1977.

King, Mervyn A., and Don Fullerton, eds. The Taxation of Income from Capital: A Comparative Study of the United States, United Kingdom, Sweden, and West Germany. Chicago: University of Chicago Press, 1984.

Levi, Maurice D. "Taxation and 'Abnormal' International Capital Flows." Journal of Political Economy 85 (June 1977): 635-646.

Mishkin, Frederic S. "Is the Fisher Effect for Real?" Journal of Economic Monetary Economics 30 (1992): 195-215.

Organization for Economic Cooperation and Development, Taxing Profits in a Global Economy: 
Domestic and International Issues. Paris: OECD, 1992.

Poterba, James M. "Tax Subsidies to Owner-Occupied Housing: An Asset Market Approach." Quarterly Journal of Economics 99 (November 1994): 729-745.

Prakken, Joel L., Chris P. Varvares, and Laurence H. Meyer. "Tax Reform and Potential Output: A Retrospective Analysis of the Tax Reform Act of 1986," Carnegie-Rochester Conference Series on Public Policy 35 (1991): 113-180. 
TABLE 1

EQUIPMENT USER COST

CLOSED ECONOMY CASE: $\eta=.3$

\begin{tabular}{|llll|}
\hline inflation rate & 7 year life & 5 year life & 3 year life \\
0 & .209 & .266 & .401 \\
.02 & .218 & .276 & .412 \\
.04 & .227 & .286 & .422 \\
.06 & .235 & .295 & .432 \\
.08 & .244 & .303 & .442 \\
.10 & .251 & .311 & .451 \\
.12 & .259 & .320 & .461 \\
\hline
\end{tabular}

TABLE 2

EQUIPMENT USER COST

CLOSED ECONOMY CASE: $\eta=.0$

\begin{tabular}{|llll|}
\hline inflation rate & 7 year life & 5 year life & 3 year life \\
0 & .209 & .266 & .401 \\
.02 & .218 & .276 & .412 \\
.04 & .227 & .285 & .422 \\
.06 & .235 & .294 & .432 \\
.08 & .243 & .302 & .441 \\
.10 & .251 & .311 & .450 \\
.12 & .258 & .318 & .459 \\
\hline
\end{tabular}


TABLE 3

EQUIPMENT USER COST

OPEN ECONOMY CASE: $\eta=.3$

\begin{tabular}{|lllllll|}
\hline inflation & $\begin{array}{l}7 \text { year } \\
\text { equity }\end{array}$ & $\begin{array}{l}5 \text { year } \\
\text { equity }\end{array}$ & $\begin{array}{l}3 \text { year } \\
\text { equity }\end{array}$ & $\begin{array}{l}7 \text { year } \\
\text { debt }\end{array}$ & $\begin{array}{l}5 \text { year } \\
\text { debt }\end{array}$ & $\begin{array}{l}3 \text { year } \\
\text { debt }\end{array}$ \\
0 & .223 & .281 & .416 & .195 & .252 & .387 \\
.02 & .229 & .287 & .423 & .190 & .248 & .384 \\
.04 & .234 & .293 & .430 & .186 & .244 & .380 \\
.06 & .239 & .298 & .436 & .181 & .240 & .377 \\
.08 & .244 & .303 & .442 & .175 & .234 & .372 \\
.10 & .248 & .308 & .448 & .169 & .229 & .368 \\
.12 & .252 & .313 & .454 & .162 & .223 & .363 \\
\hline
\end{tabular}

TABLE 4

EQUIPMENT USER COST

OPEN ECONOMY CASE: $\eta=0$

\begin{tabular}{|lllllll|}
\hline inflation & $\begin{array}{l}7 \text { year } \\
\text { equity }\end{array}$ & $\begin{array}{l}5 \text { year } \\
\text { equity }\end{array}$ & $\begin{array}{l}3 \text { year } \\
\text { equity }\end{array}$ & $\begin{array}{l}7 \text { year } \\
\text { debt }\end{array}$ & $\begin{array}{l}5 \text { year } \\
\text { debt }\end{array}$ & $\begin{array}{l}3 \text { year } \\
\text { debt }\end{array}$ \\
0 & .223 & .281 & .416 & .195 & .252 & .387 \\
.02 & .229 & .287 & .423 & .191 & .248 & .384 \\
.04 & .234 & .292 & .429 & .186 & .244 & .381 \\
.06 & .238 & .297 & .435 & .181 & .240 & .377 \\
.08 & .242 & .302 & .440 & .176 & .235 & .373 \\
.10 & .246 & .306 & .446 & .170 & .230 & .369 \\
.12 & .249 & .310 & .451 & .164 & .225 & .364 \\
\hline
\end{tabular}


TABLE 5

STRUCTURES USER COST

CLOSED ECONOMY, $\eta=.3$

\begin{tabular}{|lll|}
\hline inflation & 39 year life & 27 year life \\
0 & .091 & .102 \\
.02 & .100 & .111 \\
.04 & .107 & .119 \\
.06 & .114 & .127 \\
.08 & .119 & .133 \\
.10 & .125 & .139 \\
.12 & .130 & .144 \\
\hline
\end{tabular}

TABLE 6

STRUCTURES USER COST

CLOSED ECONOMY,$\eta=0$

\begin{tabular}{|lll|}
\hline inflation & 39 year life & 27 year life \\
0 & .091 & .102 \\
.02 & .100 & .111 \\
.04 & .107 & .119 \\
.06 & .113 & .127 \\
.08 & .119 & .133 \\
.10 & .125 & .139 \\
.12 & .130 & .144 \\
\hline
\end{tabular}


TABLE 7

STRUCTURES USER COST

OPEN ECONOMY, $\eta=.3$

\begin{tabular}{|lllll|}
\hline inflation & $\begin{array}{l}39 \text { year } \\
\text { equity }\end{array}$ & $\begin{array}{l}27 \text { year } \\
\text { equity }\end{array}$ & $\begin{array}{l}39 \text { year } \\
\text { debt }\end{array}$ & $\begin{array}{l}27 \text { year } \\
\text { debt }\end{array}$ \\
0 & .115 & .124 & .082 & .092 \\
.02 & .118 & .130 & .076 & .087 \\
.04 & .121 & .134 & .068 & .079 \\
.06 & .124 & .138 & .059 & .071 \\
.08 & .125 & .142 & .050 & .061 \\
.10 & .127 & .145 & .040 & .050 \\
.12 & .128 & .148 & .030 & .038 \\
\hline
\end{tabular}

TABLE 8

STRUCTURES USER COST

OPEN ECONOMY, $\eta=.0$

\begin{tabular}{|lllll|}
\hline inflation & $\begin{array}{l}39 \text { year } \\
\text { equity }\end{array}$ & $\begin{array}{l}27 \text { year } \\
\text { equity }\end{array}$ & $\begin{array}{l}39 \text { year } \\
\text { debt }\end{array}$ & $\begin{array}{l}27 \text { year } \\
\text { debt }\end{array}$ \\
0 & .115 & .124 & .082 & .092 \\
.02 & .118 & .130 & .076 & .087 \\
.04 & .121 & .134 & .068 & .079 \\
.06 & .122 & .138 & .060 & .071 \\
.08 & .124 & .142 & .051 & .061 \\
.10 & .125 & .145 & .042 & .050 \\
.12 & .126 & .148 & .032 & .038 \\
\hline
\end{tabular}


TABLE 9

Change in Deadweight Loss from Reducing Inflation (percent of steady-state consumption)

\begin{tabular}{|ll|} 
Key Parameters & Change in Deadweight Loss \\
$\sigma=\omega=\mathrm{e}=1$ & -.01 \\
$\sigma=\omega=1 ; \mathrm{e}=.25$ & -.03 \\
$\sigma=\omega=1 ; \mathrm{e}=2$ & .00 \\
$\sigma=\omega=.25 ; \mathrm{e}=1$ & .00 \\
$\sigma=2 ; \omega=.25 ; \mathrm{e}=1$ & .02 \\
\hline
\end{tabular}

$\sigma=$ elasticity of substitution between capital and labor $\omega=$ elasticity of substitution among capital goods (and land) $\mathrm{e}=$ intratemporal elasticity of substitution in consumption 


\section{FIGURE 1}

\section{Effects of an Anticipated Decline in Inflation on the User Cost and the Capital Stock}

(7 Year Life; Tax Adjusted Fisher Effect)
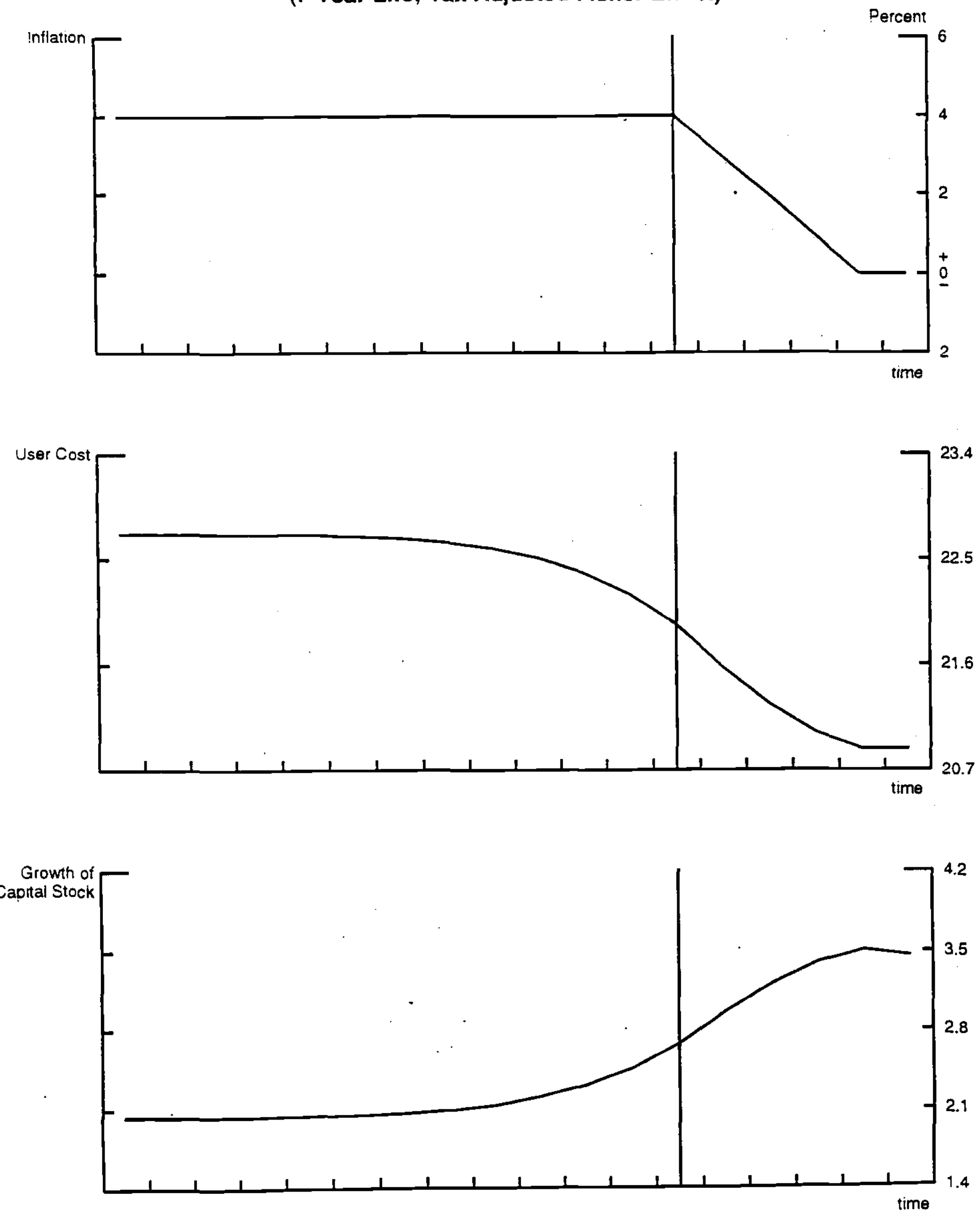
FIGURE 2

Effects of an Anticipated Decline in Inflation

on the User Cost and the Capital Stock

(7 Year Life; Tax Adjusted Fisher Effect)
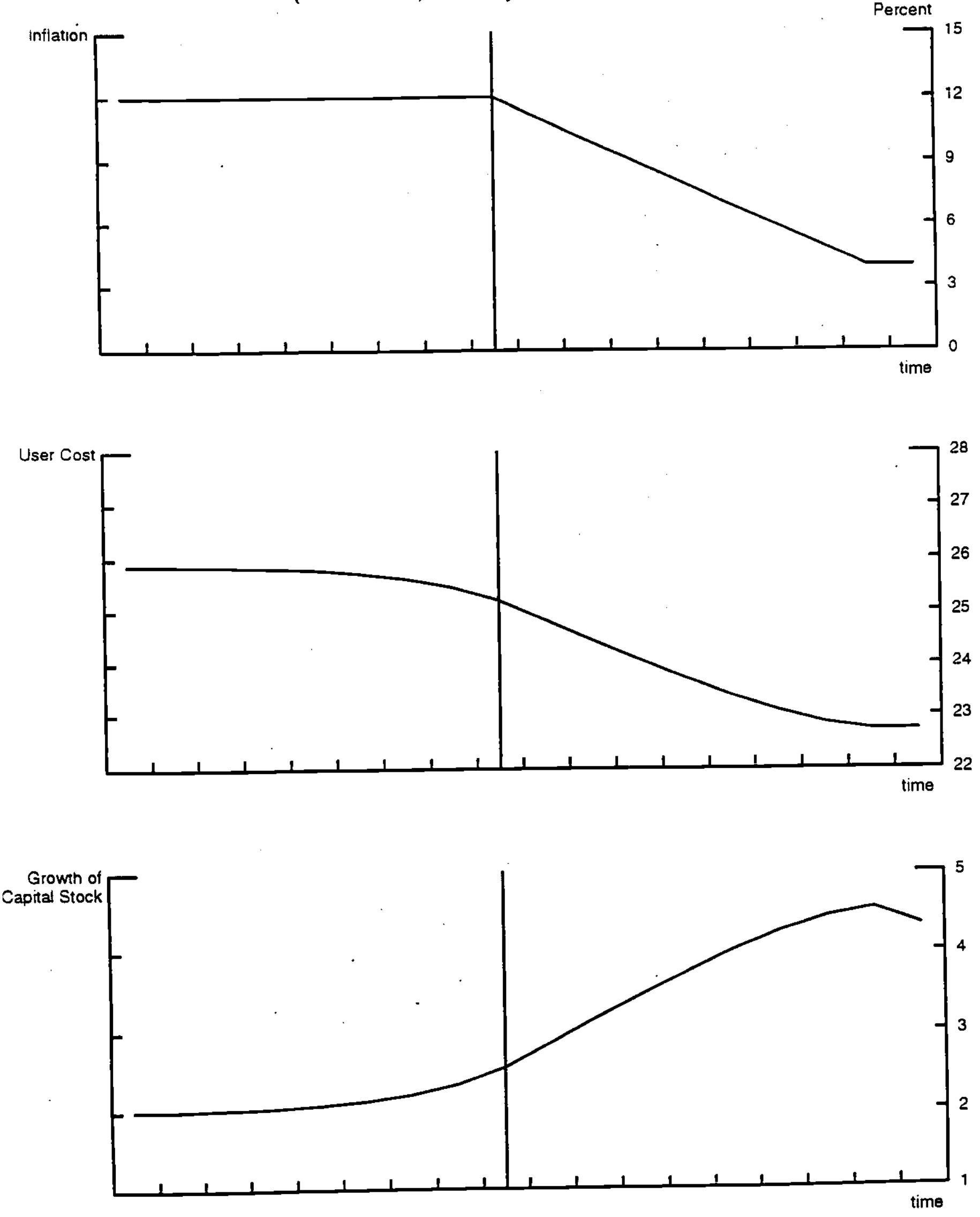


\section{FIGURE 3}

Effects of an Unanticipated Increase in Inflation

on the User Cost and the Capital Stock

(7 Year Life; Tax Adjusted Fisher Effect)
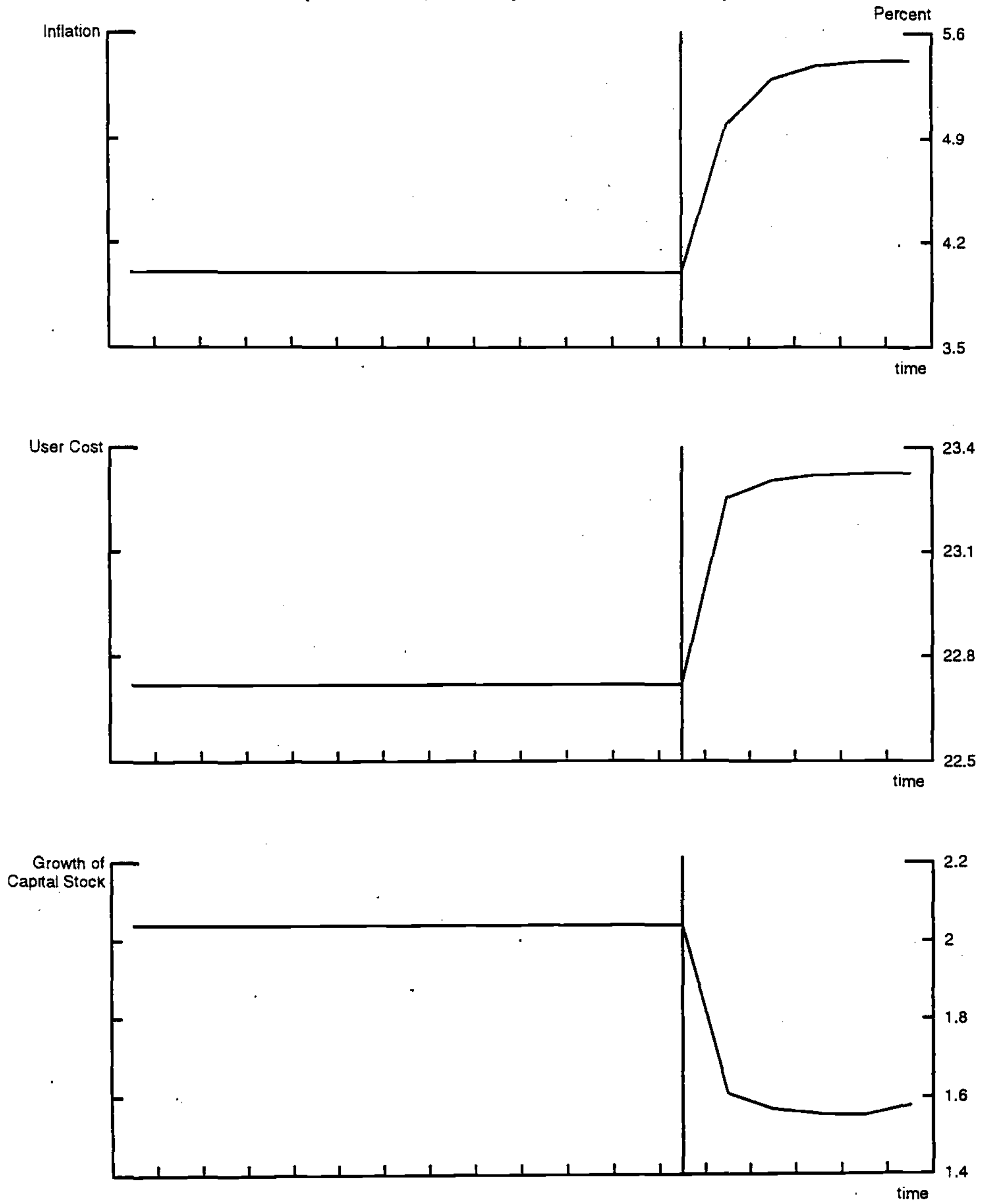